\title{
OXYFINES Technique for Upgrading Zinc Containing Blast Furnace Sludge-Part 1: Pilot Trials
}

\author{
Katarina Lundkvist ${ }^{1, *}$, Sara Rosendahl ${ }^{1}$, Fredrik Nyman ${ }^{2}$, Kristofer Bölke ${ }^{2}$, \\ Lennart Gustavsson ${ }^{3}$, Daniel Söderström ${ }^{3}$ and Anita Wedholm ${ }^{3}$ \\ 1 Swerim AB, SE-971 25 Luleå Box 812, Sweden; sara.rosendahl@swerim.se \\ 2 Linde Gas AB, SE-169 68 Solna, Sweden; fredrik.nyman@linde.com (F.N.); kristofer.bolke@linde.com (K.B.) \\ 3 SSAB Europe, SE-971 88 Luleå, Sweden; lennart.gustavsson@ssab.com (L.G.); \\ daniel.soderstrom@ssab.com (D.S.); anita.wedholm@ssab.com (A.W.) \\ * Correspondence: katarina.lundkvist@swerim.se; Tel.: +4610-489-09-70
}

Received: 12 October 2020; Accepted: 27 October 2020; Published: 4 November 2020

\begin{abstract}
In the Swedish steel industry, much work is put on further increasing the recycling and use of residual materials. However, blast furnace sludge is one residual which currently, despite its valuable contents of iron and carbon, is put on landfill or long-term storage due to its zinc content. Linde has developed the OXYFINES technique which is suitable for upgrading of fine particulate and zinc containing materials. The material is fed to the OXYFINES burner whereby its zinc content is vaporised to a generated dust phase whereas other non-gasifiable contents, such as iron, forms an oxidic sinter phase in the bottom of the reactor. The technique has proven a high degree of zinc separation, is relatively flexible and straightforward, and does not require sludge pre-treatment such as drying. Pilot set-up and trials, using the OXYFINES technique, were performed at Swerim's research facility. In the trials, the effects from altering different process parameters were tested aiming to develop an optimal concept for upgrading the blast furnace sludge. The pilot trials' results showed the required process settings to attain a high degree of zinc separation from the sludge, and to generate an iron oxide product, suitable for straightforward charging to the steelmaking process.
\end{abstract}

Keywords: pilot trials; OXYFINES technique; zinc containing sludge; residual upgrading

\section{Introduction}

The production of iron and steel generates a variety of residual materials such as dust, sludge, scales, and slag. Much effort is devoted to finding possible ways of improving the material efficiency by utilising the residual materials and thereby minimising long-term stored or landfilled amounts. Corporate aspirations on sustainability, costs, and space for the construction of new storage-/landfill sites, are motivators for the further strive for increased recycling and use of residual materials. A recent review publication, analysing the most recent results on the reuse and recycling of residual materials of the steelmaking cycles, concludes that, an increased quality of the residual materials is essential in order to improve the material use and recovery rates [1]. New technological solutions are required for achieving higher by-product qualities and hence increasing their utilisation in an environmental and economic sustainable way.

Established routes for recycling in ore-based steel production are through sintering process, via injection of the blast furnace (BF) flue dust in the $\mathrm{BF}$ and by charging cold-bonded briquettes, basic oxygen furnace (BOF) slag and desulphurisation scrap to the BF [2-6]. The Nordic sintering plants have been closed due to environmental issues whereas the recycling of in-plant fines in Swedish ore-based steel production is mainly by BF flue dust injection and via cement-bound briquettes charged to the BF. The BF briquettes consists of a variety of iron-, carbon- and lime-containing residual materials 
such as fine-grained scrap, dust and sludge. Other direct recycling is made via BOF slag charged to the $\mathrm{BF}$ and the recovery of scrap arising from the production chain.

In Sweden, up to 20,000 tonnes of BF sludge (dry weight) is annually generated from hot metal production. Although the sludge contains substantial amounts of valuable elements, such as iron (ca. 35\%) and carbon (ca. 25\%), all freshly generated BF sludge is deposited in sludge ponds at the production site today. The reason for this is the zinc $(\mathrm{Zn})$ content in the sludge, which due to process related restrictions makes it unsuitable for a direct recovery to the existing in-plant processes.

Zinc occurs in a cyclic flow in the BF, which has negative effects on the consumption of coal and coke and thus the $\mathrm{CO}_{2}$ emission. Zinc may cause processing issues by acting as an adhesive and disrupting the flow of materials through the furnace $[7,8]$ and induce problems in the nozzles through which hot air is supplied to the BF process.

The issues associated with accumulating zinc limits the recovery of residual materials. The zinc content of the BF material feed has increased as a result of an increased recovery via the BF briquettes. The main parts of the zinc exit with the exhaust gases to be collected in the BF's gas purification system, especially in the finest particles proportion separated by the scrubber system in which BF sludge is generated. In recent times also parts of old BF sludge, i.e., with considerably lower zinc content compared to the freshly generated sludge, have been used in the BF briquettes, Figure 1. Over the years, the increased recycling of zinc-containing materials to the $\mathrm{BF}$, has accumulated the zinc, mainly in the generated BF sludge [9].

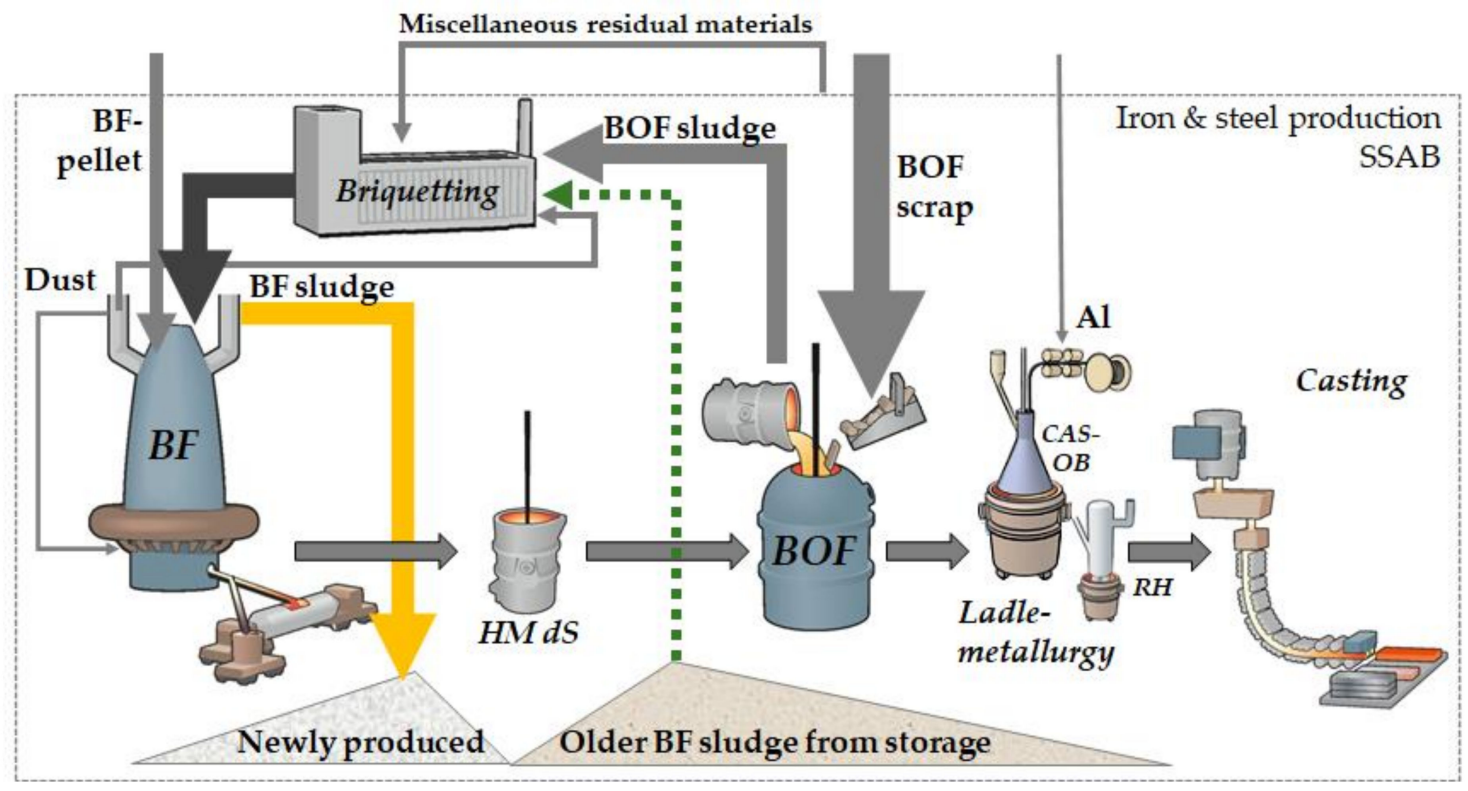

Figure 1. Schematics of the zinc flow in the iron and steel production route at SSAB Europe, Luleå.

The zinc content in the BF sludge (less than $1 \% \mathrm{Zn}$ ) is too low for external recovery, for instance in zinc production, for which a desired zinc content in the sludge is at least $30 \%$. In addition to its zinc content, the BF sludge also has a high moisture content. BF sludge taken directly from the gas purification system has a moisture content of ca. $96 \mathrm{wt}$. \% and the sludge taken from sludge ponds includes some $50 \mathrm{wt}$ \% moisture.

Treatment in a separate unit process is proposed to improve and to optimise the utilisation of residual materials. By the treatment, raw material products, derived from residual materials, can be introduced in the production route in an optimal stage, or to be applicable for external usages $[10,11]$.

The sintering process is a pre-treatment step, used in the production of iron and which comprises the agglomeration of fine mineral particles (e.g., fine particulate iron ores, iron oxide residuals such as zinc containing dusts and mill scale together with lime raw materials) into a porous and semi-molten 
lumpy mass $[12,13]$. However, a previous study on the recovery of fine-grained dust/sludge via sintering plants, showed the sintering operations to be inefficient in zinc removal [14].

The use of established thermal treatment technologies, such as reduction furnaces e.g., rotary heart furnace (RHF), [15,16] OxyCup [17] or Waelz kiln, [18] requires in general considerably large amounts of residual materials and entails high investment costs. Prior to reprocessing, using these techniques, the BF sludge also requires pre-treatment such as drying and agglomeration. In addition, it is essential that the new residuals generated in such a process, e.g., dust, sludge or slag, in turn are possible to be utilised.

In a study from the literature, the composition of BF sludge was examined regarding possibilities to separate different elements. The results of the study showed that the concentration of the investigated elements significantly depends on the particle size. Coarser particles $(>100 \mu \mathrm{m})$ had a higher proportion of carbon, and fine-grained particles $(<20 \mu \mathrm{m})$ showed enrichment of iron and of zinc, lead, and cadmium, due to their condensation on the surfaces of the particles [19].

Hydrocycloning has been used for the upgrading of BF sludge, by removing zinc and recovering iron and carbon $[20,21]$. However, a previous study performed by SSAB, on the prospect of mechanically separating the zinc content of the BF sludge in a zinc-rich fraction via, e.g., a hydro cyclone showed that the zinc content of the BF sludge was difficult to separate and independent of the fractions as the $\mathrm{BF}$ sludge is very fine grained. It was concluded that mechanical fractioning of the specific BF sludge is not applicable for zinc separation.

Leaching is another alternative for zinc separation by either conventional approaches or by microwave-assisted leaching [22-24]. From the results of microwave-assisted leaching the dissolution rate of zinc was improved to $92 \%$ [25].

Linde has developed the OXYFINES technique for which dust or sludge is fed to a special designed OXYFINES burner whereby components such as zinc, sulphur and alkalis at various degrees are vaporised to a generated dust phase. The OXYFINES technique is relatively straightforward and cost-effective and previous tests have shown a high degree of zinc separation and with which no pre-treatment of sludge, such as drying, is required. In the process the carbon in the BF sludge is used for the reduction of zinc, whereas other non-gasifiable contents in the BF sludge, such as iron, form an oxidic phase in the bottom of the reactor, in either molten or semi-molten sintered form, depending on process temperature $[26,27]$.

The zinc evaporation is enhanced by higher temperature and lower oxidation potential. By the utilisation of the coal content of the BF sludge, the degree of oxidation is increased and thereof an increased oxygen potential is attained in the reaction zone. Increased oxygen potential has a negative effect on the zinc evaporation which takes place in the form of elemental zinc vapor generally described by the reaction:

$$
\mathrm{ZnO}(\mathrm{s})+\mathrm{C}(\mathrm{s}) \rightarrow \mathrm{Zn}(\mathrm{g})+\mathrm{CO}(\mathrm{g})
$$

In this regard, an optimal level of oxidation is proposed to be found in the process, measured with $\mathrm{CO}_{2} / \mathrm{CO}$ ratio (and $\mathrm{H}_{2} \mathrm{O} / \mathrm{H}_{2}$ ratio) or with oxygen potential, $\mathrm{Lg}\left(\mathrm{pO}_{2} / \mathrm{bar}\right.$ ) (or $\mathrm{RT} \ln \left(\mathrm{pO}_{2} / \mathrm{bar}\right)$ ) [27].

Pilot trials using OXYFINES technique for upgrading BF sludge was performed in this research work in an up-scaled test set-up. Earlier, the OXYFINES technique was tested for material treatment, i.e., both dry dusts and sludges at temperatures of $1300-1500{ }^{\circ} \mathrm{C}[26,27]$. In the performed pilot trials of this work, temperatures were kept in a lower range, between $1100-1300^{\circ} \mathrm{C}$ thereby avoiding melting to the point of liquefaction, and preferably generating a sintered product. The sinter product generated in the pilot trials was intended for use as raw material in steel production and the zinc dust was in this case evaluated for its suitability as raw material in zinc production.

The study aimed to verify and to develop the OXYFINES technique to enable the recovery of zinc-containing BF sludge by refining and making useful products of the valuable contents of the BF sludge. By the pilot trials the OXYFINES technique was demonstrated and developed for increased knowledge by evaluating the effects of different process parameters on the BF sludge processing and upgrading. 
The results of the pilot trials showed a very stable, easily operated, and adjustable OXYFINES process. An iron-rich sinter product suitable for utilisation in the steel production was obtained. The prospects of a successful implementation of the OXYFINES concept have positive effects on sustainability mainly by improved material efficiency and by waste prevention. The recovery of BF sludge decreases landfill use and using generated OXYFINES products contributes to the value chain by reduced need for virgin raw materials.

\section{Materials and Methods}

The SSAB steel plant in Luleå is part of the SSAB Europe group with ore-based steel plants in Sweden and in Finland. The operation in Luleå, Sweden is focused on production of slabs for strip steel. The plant is equipped with a coke plant, one BF (2.3 Mtonne/year), two units for hot metal desulphurisation (DeS) in transfer ladles, two LD-type basic oxygen furnaces (BOF) with 130 tonne tap weight, two CAS-OB units for ladle treatment, one RH vacuum degasser unit and two single stranded slab-casting machines. Total annual crude steel production capacity is 2.2 Mtonne [28].

Based on average reference production data of the BF, weeks 51 to 52 , at SSAB Lulea works in the year 2019, 1996 ktonne hot metal (HM) was produced from iron ore pellets (ca $1330 \mathrm{~kg} / \mathrm{tHM}$ ). Additives such as limestone of ca $28 \mathrm{~kg} / \mathrm{tHM}$, BOF slag of ca $21 \mathrm{~kg} / \mathrm{tHM}$ and BF briquettes of ca $98 \mathrm{~kg} / \mathrm{tHM}$ are charged at the top. Hot blast air together with pulverised coal injection (PCI) of ca $135 \mathrm{~kg} / \mathrm{tHM}$ and $\mathrm{BF}$ dust injection of ca $7 \mathrm{~kg} / \mathrm{tHM}$ supplied from below via the tuyeres. In addition to the HM produced, ca $167 \mathrm{~kg} / \mathrm{tHM}$ of BF slag, ca $21 \mathrm{~kg} / \mathrm{tHM}$ of BF dust and ca $6 \mathrm{~kg} / \mathrm{tHM}$ of BF sludge (dry weight) was generated.

Two pilot trial campaigns were carried out at Swerim's pilot plant facilities in Luleå during the summer months of 2019 (in May and in August) with a corresponding three trial days each. Moisture measurements of the BF sludge and preparatory tests were made to evaluate the required moisture content for a pumpable sludge and to simultaneously avoid unnecessarily high moisture content regarding the OXYFINES process energy requirements. A suitable moisture content of the BF sludge was assumed to be about $55 \%$.

The BF sludge used in the pilot trials was collected from one of the BF sludge ponds at the SSAB steel production site. The principle of the pilot arrangement, Figure 2, included pumping the BF sludge from containers for feeding into the cylinder-shaped furnace via the OXYFINES burner together with oxygen and propane.

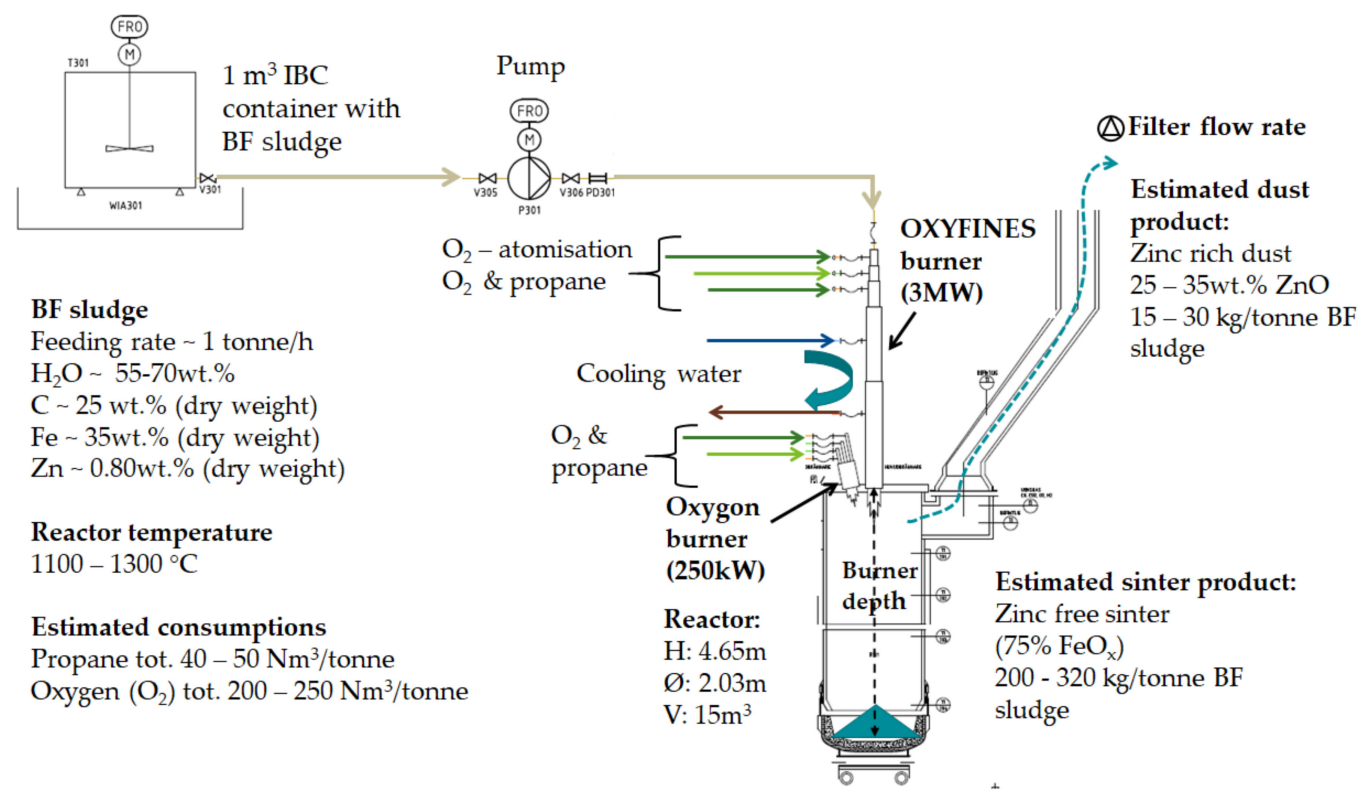

Figure 2. The principle of OXYFINES pilot set-up for BF sludge upgrading and expected products. 
The sludge fed to the OXYFINES burner (Linde Gas AB, Solna, Sweden) is atomised, and the water content evaporates in the burner flame. Zinc and other volatile elements leave the reactor, via the exhaust gases forming a zinc rich dust, intended as a raw material for the zinc production. The non-gasifiable contents, mainly iron oxides, form a virtually zinc free product for utilisation as a raw material in the steel production (i.e., in $\mathrm{BF}$ or in $\mathrm{BOF}$ ).

The OXYFINES burner is a water-cooled main burner with variable insertion depth in the reactor and with atomisation of sludge via oxygen. The media for the burner is oxygen and propane depending on the required $\mathrm{CO}$ content in furnace gas analysis operated via the process control system. The Oxygon support burner is a water-cooled burner with a flame guard. Media to the support burner for heating and flame retention $(250 \mathrm{~kW})$ are oxygen and propane. The support burner was mainly used for heating the furnace shaft, up to $800^{\circ} \mathrm{C}$.

The trials were carried out as a series of batch tests with altered process conditions, primarily to evaluate the influence on the zinc separation degree and quality, as well as produced amounts of sinter dust. The batches in the first campaign were performed by keeping different temperatures, within the range $1100{ }^{\circ} \mathrm{C}$ to $1300{ }^{\circ} \mathrm{C}$, constant and altering the stoichiometry (the $\mathrm{CO} / \mathrm{CO}_{2}$ ratio) in the furnace gas analysis from ca 2 to $10 \mathrm{Vol}$. \% CO.

The process temperature in the pilot trials was intended to be kept as low as possible to minimise energy consumption, but at the same time operating at a temperature sufficient to produce a virtually zinc free sinter product. Temperature measurements were made via four thermocouples placed through the furnace wall for measuring the temperature profile in the furnace shaft. Furnace gas analyses were taken for $\mathrm{CO}, \mathrm{CO}_{2}, \mathrm{O}_{2}$ and $\mathrm{H}_{2}$. Exhaust gas analyses (i.e., $\mathrm{CO}, \mathrm{CO}_{2}$, and $\mathrm{O}_{2}$ ) as well as temperature and flow measurement were taken in the exhaust duct and off-gas system hose filter.

In the second pilot trials campaign, the focus was on reducing the dust generation and thus increasing the zinc concentration in the dust. Four trial batches were performed with reduced sludge feeding rate, two with adjusted depth of the OXYFINES burner in the reactor, and further one batch was made with reduced oxygen for the atomisation flow. During the campaigns also the filter flow, i.e., off-gas flow through the exhaust purification filter, was altered in three different flow rates.

The sinter product was collected in a sandbox on a trolley. The dust product was collected in barrels. Material samples were taken for analyses on the BF sludge moisture content in the separate batches. Further samples were taken for chemical analysis of the BF sludge, generated sinter, and dust products for evaluating e.g., the zinc separation degree, iron contents and consumed carbon. Chemical analysis of the BF sludge and generated products from the trials was performed via X-ray fluorescence (XRF) analysis from melt iso formation, Leco (for $\mathrm{C}$ and $\mathrm{S}$ ) and wet chemical analysis of zinc content.

\section{Results}

In general, the results from the pilot trials demonstrated a very stable OXYFINES process with easily controlled temperature and Vol. \% CO in the furnace atmosphere. A refined sinter product, with almost no zinc content, and a dry zinc containing dust, was generated. The average chemical analyses of the BF sludge, generated OXYFINES dust and sinter as well as the sand used in sandboxes from campaigns (C) No. 1 and 2 are presented in Table 1.

The sinter was easily crushed into lumps after cooling, practically without any fines' generation, making it a suitable product for handling, and charging to the steelmaking processes. Table 2 summarises the performed trial batches of the two campaigns. Average moisture content $\left(\mathrm{H}_{2} \mathrm{O}\right)$ in the BF sludge in the campaigns was $58 \%$. In campaign 1, i.e., batches indexed No. 1 to 8 , process settings were made for evaluating the relation of temperature and Vol.\% CO to attain a high zinc separation degree. 
Table 1. Average chemical analyses of the BF sludge, generated OXYFINES dust and sinter as well as the sand used in sandboxes from campaigns (C) No. 1 and 2.

\begin{tabular}{|c|c|c|c|c|c|c|c|c|c|c|}
\hline \% Dry wt. & $\begin{array}{c}\text { BF Sludge } \\
\text { avg. C No. } 1\end{array}$ & $\begin{array}{l}\text { BF Sludge } \\
\text { avg. C No. } 2\end{array}$ & $\begin{array}{l}\text { BF sludge } \\
\text { Total avg. }\end{array}$ & $\begin{array}{l}\text { Dust avg.C } \\
\text { No. } 1\end{array}$ & $\begin{array}{l}\text { Dust avg.C } \\
\text { No. } 2\end{array}$ & $\begin{array}{l}\text { Dust Total } \\
\text { avg. }\end{array}$ & $\begin{array}{l}\text { Sinter avg. } \\
\text { C No. } 1\end{array}$ & $\begin{array}{l}\text { Sinter avg. } \\
\text { C No. } 2\end{array}$ & $\begin{array}{l}\text { Sinter Total } \\
\text { avg. }\end{array}$ & Sand \\
\hline Fe tot. & 34.28 & 33.25 & 33.76 & 43.70 & 43.19 & 43.45 & 47.81 & 40.85 & 44.33 & 3.03 \\
\hline $\mathrm{CaO}$ & 8.86 & 9.74 & 9.30 & 10.86 & 12.29 & 11.57 & 12.63 & 12.75 & 12.69 & 3.10 \\
\hline $\mathrm{SiO}_{2}$ & 5.11 & 5.36 & 5.24 & 4.21 & 7.74 & 5.98 & 12.40 & 21.46 & 16.93 & 74.11 \\
\hline $\mathrm{MnO}$ & 0.24 & 0.31 & 0.27 & 7.06 & 0.73 & 3.89 & 0.35 & 0.39 & 0.37 & 0.05 \\
\hline $\mathrm{P}_{2} \mathrm{O}_{5}$ & 0.16 & 0.17 & 0.17 & 3.63 & 0.26 & 1.94 & 0.22 & 0.23 & 0.22 & 0.16 \\
\hline $\mathrm{Al}_{2} \mathrm{O}_{3}$ & 2.11 & 2.20 & 2.16 & 0.58 & 3.34 & 1.96 & 4.22 & 7.59 & 5.90 & 14.87 \\
\hline $\mathrm{MgO}$ & 1.43 & 1.42 & 1.43 & 0.35 & 2.93 & 1.64 & 2.07 & 1.99 & 2.03 & 1.33 \\
\hline $\mathrm{Na}_{2} \mathrm{O}$ & 0.13 & 0.14 & 0.13 & 0.27 & 0.54 & 0.40 & 0.24 & 0.61 & 0.42 & 4.64 \\
\hline $\mathrm{K}_{2} \mathrm{O}$ & 0.09 & 0.12 & 0.10 & 0.92 & 0.37 & 0.65 & 0.32 & 0.75 & 0.54 & 3.74 \\
\hline $\mathrm{V}_{2} \mathrm{O}_{5}$ & 0.24 & 0.22 & 0.23 & 0.84 & 0.29 & 0.56 & 0.33 & 0.26 & 0.29 & 0.03 \\
\hline $\mathrm{TiO}_{2}$ & 0.28 & 0.28 & 0.28 & 0.19 & 0.35 & 0.27 & 0.42 & 0.42 & 0.42 & 0.36 \\
\hline $\mathrm{Cr}_{2} \mathrm{O}_{3}$ & 0.03 & 0.03 & 0.03 & 0.14 & 0.10 & 0.12 & 0.12 & 0.09 & 0.10 & 0.09 \\
\hline C & 24.92 & 24.02 & 24.47 & 2.14 & 0.56 & 1.35 & 2.81 & 0.04 & 1.42 & 0.08 \\
\hline S & 0.32 & 0.37 & 0.34 & 0.63 & 0.39 & 0.51 & 0.14 & 0.10 & 0.12 & 0.02 \\
\hline $\mathrm{Zn}$ & 0.74 & 0.84 & 0.79 & 3.71 & 4.00 & 3.85 & 0.23 & 0.14 & 0.18 & 0.02 \\
\hline
\end{tabular}

Table 2. Evaluated process parameters in campaigns (C) No. 1 and 2.

\begin{tabular}{|c|c|c|c|c|c|c|c|c|c|c|}
\hline C & Batch & Index & Feeding Rate & $\mathrm{H}_{2} \mathrm{O}$ & Lance Length & $\mathrm{O}_{2}$ Atomisation & Oxygon Burner & TempTgt. & CO Tgt. & Filter Flow \\
\hline No. & No. & No. & $\mathrm{kg} / \mathrm{min}$ & $\begin{array}{l}\text { wt. } \\
\%\end{array}$ & m & $\mathrm{Nm}^{3} / \mathrm{min}$ & kW & ${ }^{\circ} \mathrm{C}$ & Vol. \% & $\mathrm{Nm}^{3} / \mathrm{h}$ \\
\hline 1 & O-002 & 1 & 14 & 63 & 1 & 0.8 & 250 & 1250 & 5 & 7500 \\
\hline 1 & O-003 & 2 & 14 & 62 & 1 & 0.8 & 250 & 1300 & 5 & 7500 \\
\hline 1 & O-006 & 3 & 14 & 59 & 1 & 0.8 & 250 & 1250 & 5 & 3500 \\
\hline 1 & O-007 & 4 & 14 & 64 & 1 & 0.8 & 250 & 1100 & 1 & 3500 \\
\hline 1 & O-008 & 5 & 14 & 68 & 1 & 0.8 & 250 & 1200 & 5 & 3500 \\
\hline 1 & O-009 & 6 & 14 & 54 & 1 & 0.8 & 250 & 1250 & 10 & 3500 \\
\hline 1 & O-010 & 7 & 14 & 59 & 1 & 0.8 & 250 & 1200 & 10 & 3500 \\
\hline 1 & O-011 & 8 & 14 & 55 & 1 & 0.8 & 250 & 1250 & 7 & 3500 \\
\hline 2 & O-012 & 9 & 10 & 57 & 1 & 0.8 & 0 & 1270 & 8 & 6000 \\
\hline 2 & O-013 & 10 & 8 & 56 & 1 & 0.8 & 0 & 1270 & 8 & 6000 \\
\hline 2 & O-014 & 11 & 10 & 56 & 1 & 0.6 & 0 & 1270 & 8 & 6000 \\
\hline 2 & O-015 & 12 & 10 & 57 & 1.5 & 0.8 & 0 & 1270 & 8 & 6000 \\
\hline 2 & O-016 & 13 & 14 & 57 & 1.5 & 0.8 & 0 & 1270 & 8 & 6000 \\
\hline
\end{tabular}


The generated sinter product was on average about 320 kilo per tonne total solids (TS). The wt. \% iron (Fe) on average $44 \%$ and coal (C) in the sinter product from the respective batches are presented in Figure 3. In most batches the main parts of the carbon contained in the BF sludge was consumed. The higher carbon contents in the sinter product in the batches indexed No. 4 and No. 7 is explained by the lower process temperature of $1100{ }^{\circ} \mathrm{C}$ and $1200{ }^{\circ} \mathrm{C}$, respectively, and thus resulted in some unreacted carbon, Table 2.

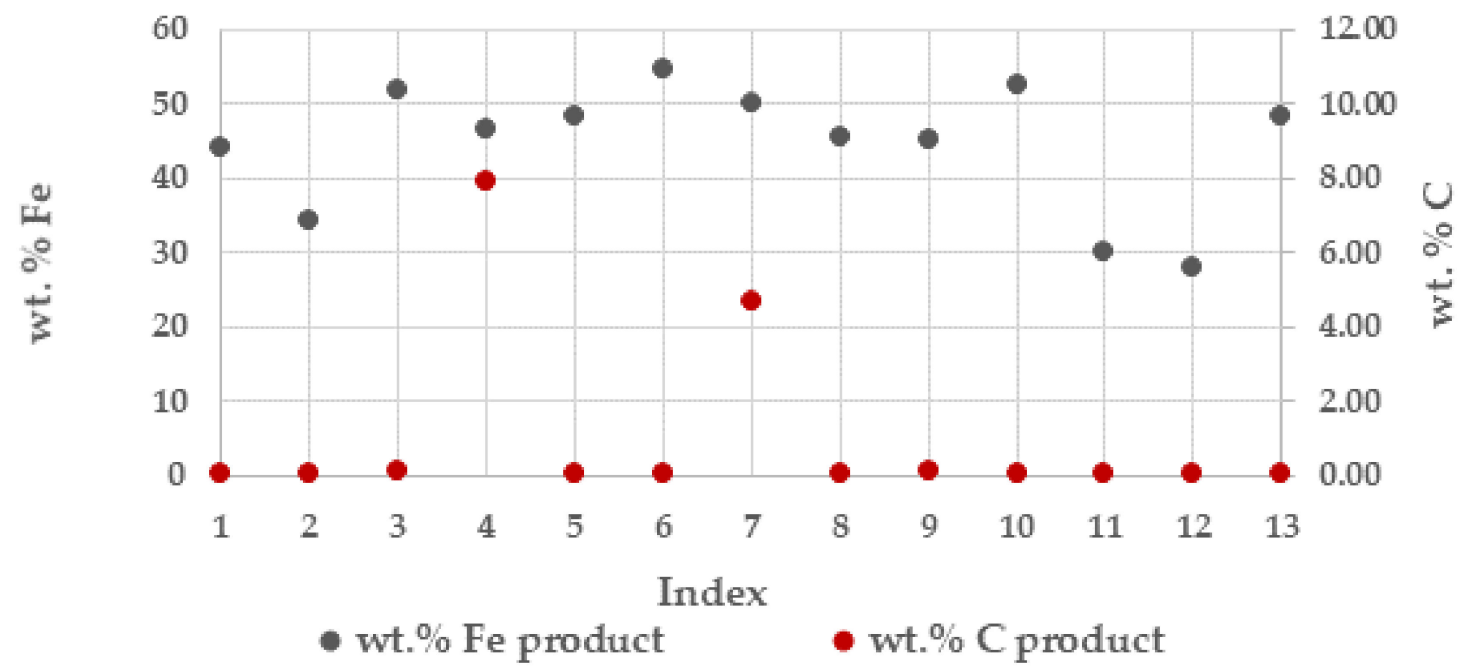

Figure 3. Wt. \% iron (Fe) and carbon $(\mathrm{C})$ in the sinter product from respective batches during the campaigns.

The results illustrated in Figure 4, shows that the temperature span between non melted and unreacted sinter product (at $1100^{\circ} \mathrm{C}$ ), and melted and reacted sinter (at $1300{ }^{\circ} \mathrm{C}$ ) was very narrow. At $1200{ }^{\circ} \mathrm{C}$, the sinter product had partially melted and reacted.

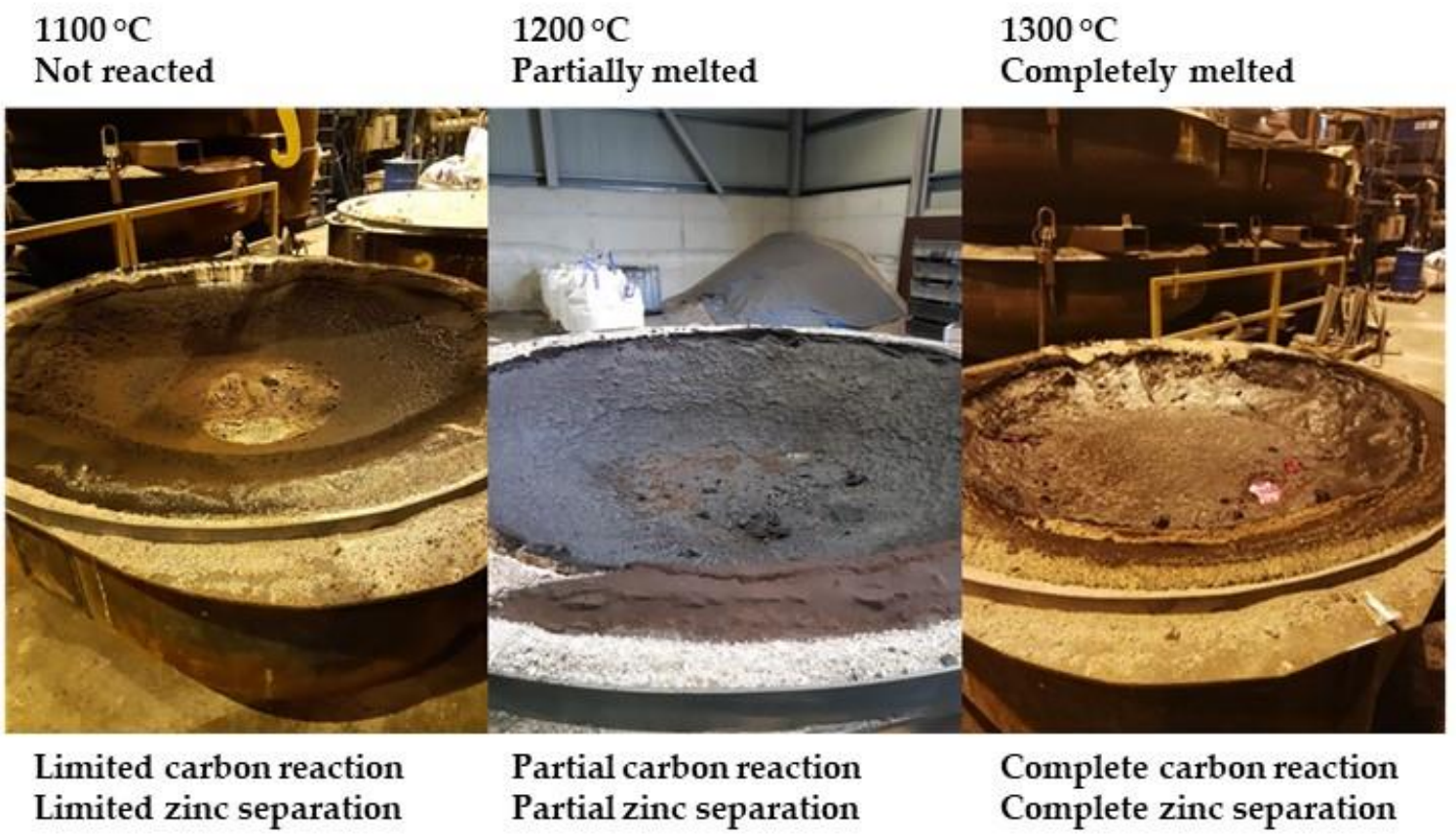

Figure 4. Sinter heating and reaction at process temperatures 1100 to $1300{ }^{\circ} \mathrm{C}$. 
The zinc separation degree in the trial batches was high, on average $93 \%$, with the highest achieved zinc separation of $97 \%$ in the batch with the index No. 6, Table 1 . The separation degree was calculated according to the equations:

$$
\begin{gathered}
\text { Zn separation }(\mathrm{kg})=\text { wt. }-\% \text { Zn in BF sludge } / 100 * \text { TS }(\mathrm{kg})+\text { wt. }-\% \text { Zn in sand } / 100 \text { * } \\
\text { sand }(\mathrm{kg})-\text { wt. } \% \text { Zn in sinter } / 100 *(\text { sinter }(\mathrm{kg})+\text { sand }(\mathrm{kg})) \\
\text { Zn separation }(\%)=\text { Zn separation }(\mathrm{kg}) /(\mathrm{wt} .-\% \\
\text { Zn in BF sludge/100* TS }(\mathrm{kg})+\mathrm{wt} .-\% \mathrm{Zn} \text { in sand } / 100 * \text { sand }(\mathrm{kg})) * 100
\end{gathered}
$$

From results of the campaign 1 , the highest zinc separation was obtained at $>5 \mathrm{Vol}$. \% CO and at temperatures $>1250{ }^{\circ} \mathrm{C}$, Figures 5 and 6 . Based on this result, process settings in campaign No. 2 was set to be $8 \mathrm{Vol} . \% \mathrm{CO}$ and $1270{ }^{\circ} \mathrm{C}$. The sample of the batch with Index No. 3 shows a low zinc reduction which is unexplained and most likely depending on the sampling or the analysis of the zinc content.

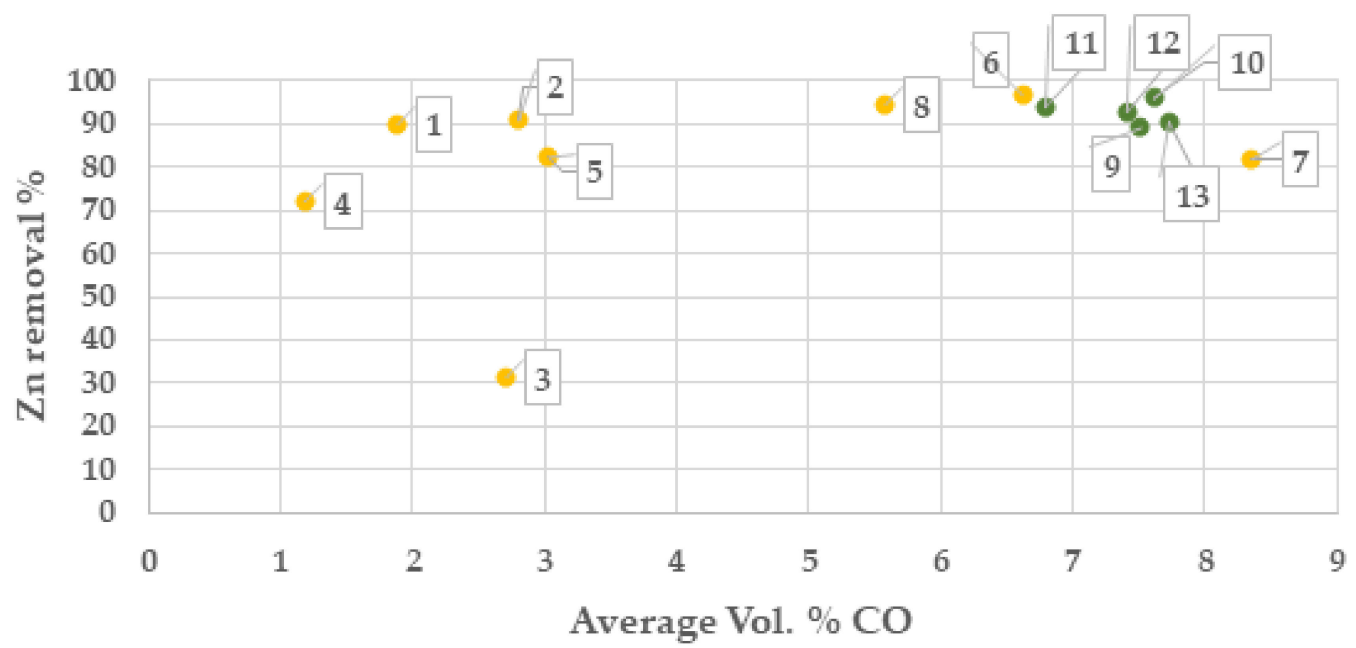

Figure 5. Zinc separation degree (\%) at average Vol. \% CO in OXYFINES reactor gas analysis (campaign 1, yellow colour and campaign 2 green colour). Points in chart are presented with index number for the respective batch.

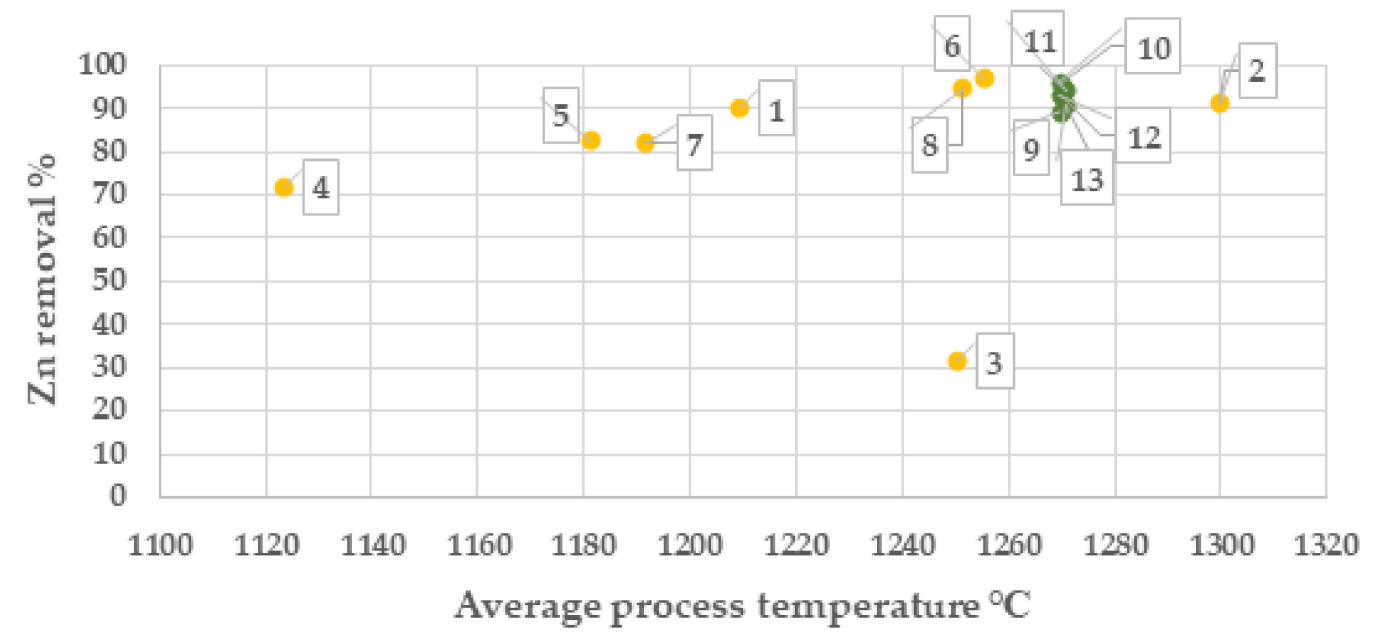

Figure 6. Zinc separation degree (\%) at average OXYFINES process temperature (campaign 1, yellow colour and campaign 2 green colour). Points in chart are presented with index number for the respective batch. 
Table 3 presents the average off-gas analysis of the pilot trial campaigns regarding the off-gas contents of $\mathrm{H}_{2} \mathrm{O}, \mathrm{H}_{2}, \mathrm{CO}, \mathrm{CO}_{2}$ and $\mathrm{O}_{2}$.

Table 3. Average off-gas analysis in campaigns ( $\left.\mathrm{Nm}^{3} / \mathrm{min}\right)$.

\begin{tabular}{cc}
\hline Content & $\mathbf{N m}^{3} / \mathbf{m i n}$ \\
\hline $\mathrm{H}_{2} \mathrm{O}$ & 14.41 \\
$\mathrm{H}_{2}$ & 1.40 \\
$\mathrm{CO}$ & 1.12 \\
$\mathrm{CO}_{2}$ & 4.89 \\
$\mathrm{O}_{2}$ & 0.00 \\
\hline
\end{tabular}

The dust generation was higher than expected with an average in batches of ca. 190 kilo per tonne of TS. The zinc content in the dust was at best ca. $5 \%$, with an average in the campaigns of $3.85 \%$, Figure 7.

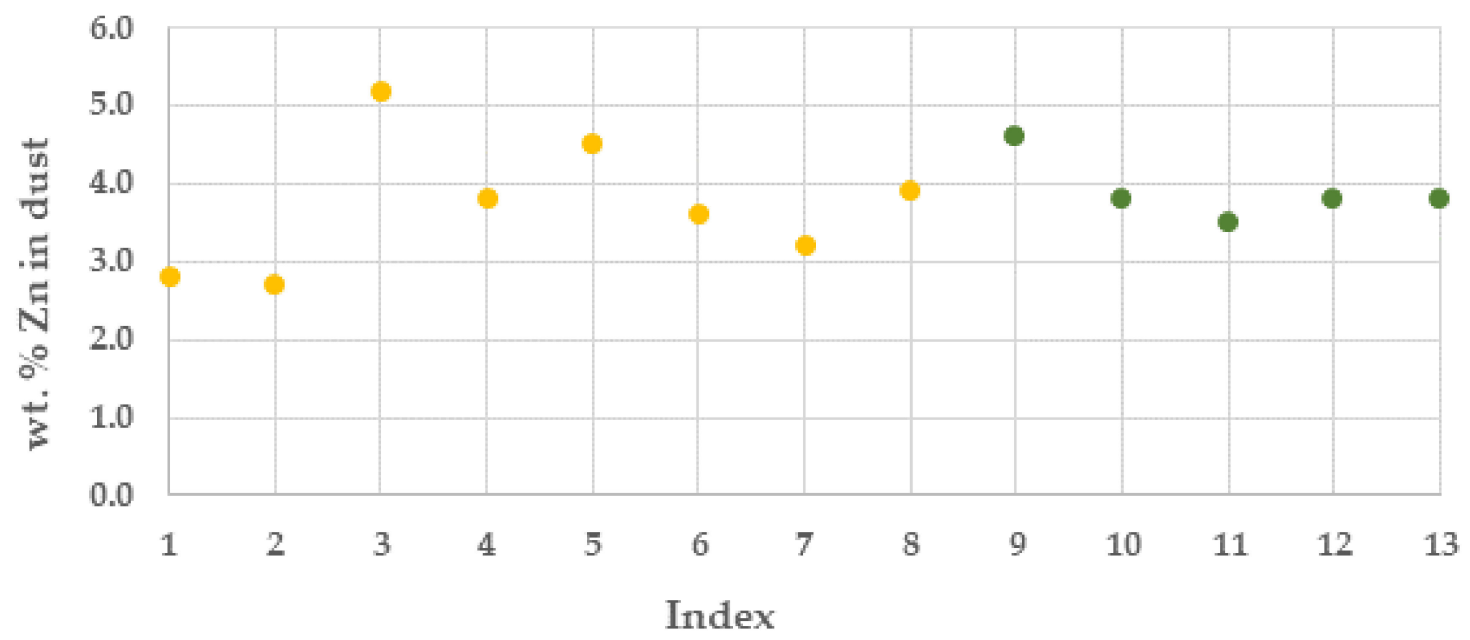

Figure 7. Zinc content (\%) in OXYFINES dust from the pilot trial campaigns (campaign 1, yellow colour and campaign 2 green colour).

The results from the campaigns show that the major influence on the dust generation was by the filter flow rate, Figure 8. The significantly reduced filter flow, from ca 7500 to ca $3500 \mathrm{Nm}^{3} / \mathrm{h}$ after the first two batches in campaign 1, resulted in the lowest dust generated. In campaign 2, the filter flow was kept constant at ca $6000 \mathrm{Nm}^{3} / \mathrm{h}$.

Altered process parameters in campaign 2 for analysing the effects on the dust generation, were; a reduced sludge feeding rate (in batches indexed No. 9 to 12), an increased burner depth (lance length) by $0.5 \mathrm{~m}$ (in batches indexed No. 12 and 13) and a reduced atomisation oxygen flow (from 0.8 to $0.6 \mathrm{Nm}^{3} / \mathrm{h}$ in the batch with index No.11), as shown in Table 2. Increasing the atomisation oxygen flow and the increased burner depth decreased the dust generation to some extent, whereas sludge feeding rate showed very little impact on the dust generation. 


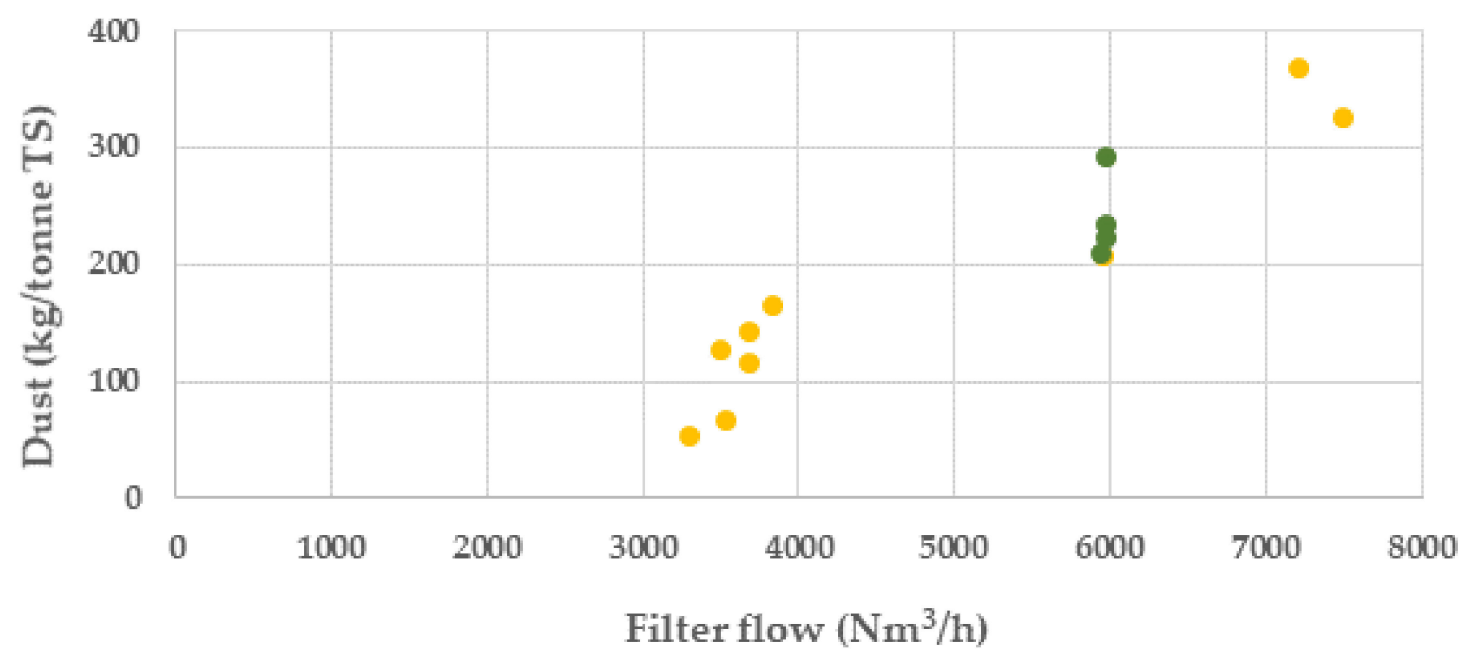

Figure 8. Dust generation in batches in kilo per tonne dry BF sludge at different filter flow rates $\left(\mathrm{Nm}^{3} / \mathrm{h}\right)$ (campaign 1, yellow colour and campaign 2 green colour).

The OXYFINES sinter, produced during the pilot trial campaigns, was tested in the BOF steel production at SSAB in Luleå. Due to including of sand from the sandbox used for gathering the sinter in the bottom of the furnace, the sinter contained ca $44 \mathrm{wt}$. \% Fe and had a basicity B2 of ca 1-2 (decreased by $\mathrm{SiO}_{2}$ from the included sand).

The sinter was charged to the BOF via the scrap chute as part of the cooling scrap in amounts of ca $1.2 \%, 1.6 \%$ and $2.4 \%$ of the total charge weight. BOF steel and slag samples were analysed against reference charge showing no quality effects and thus it seems possible to use the OXYFINES sinter product as a raw material in the BOF.

The dust product from the two campaigns was analysed theoretically by the zinc producer Boliden Mineral AB based on the dust average composition, Table 1. The zinc content in the dust was too low, ca $4 \%$ zinc compared to the required $>30 \%$, to be suitable as a raw material in the zinc production process. The other contents in the dust were comparable to the typical analysis of the iron dust today used in the zinc production.

\section{Discussion}

The pilot trials using the Linde developed OXYFINES technique presented a very stable and easily controlled process which is suitable for the separate treatment of dust and sludge, thereof achieving higher material qualities and hence increasing their utilisation.

A zinc separation degree of up to $97 \%$ was demonstrated in the trials, producing a refined sinter product, with virtually no zinc, and a dry zinc containing dust. The produced sinter was easily crushed into lumps after cooling with virtually no fines' generation, making it a suitable product for handling, and charging to the in-plant steelmaking processes i.e., in BF ironmaking or in basic oxygen furnace steelmaking.

The dust produced in the pilot trials had a zinc content of ca. $5 \%$ zinc whereas the prerequisite on the dust, as a raw material in zinc production, is a zinc content corresponding to $>30 \%$. However, the overall chemical compositions of the dust were similar to other steelmaking dusts being used in zinc production.

By further work, the reduction of dust generation, and thereby increasing the zinc content in the dust, can be managed by actions such as decreased leakage air to the off-gas flow and by reducing the off-gas filter flow. Significant effects on dust amounts were seen in the trials by reducing the filter flow from $7500 \mathrm{Nm}^{3} / \mathrm{h}$ to $3500 \mathrm{Nm}^{3} / \mathrm{h}$. Also, the required zinc concentration in the dust can be met by higher zinc concentration in the BF sludge or by recirculating the generated dust in the OXYFINES 
process. One other possibility of further improvement is installing a refractory lined cyclone on the off-gas exit of the reactor.

In the context of available thermal treatment technologies, such as reduction furnaces, the OXYFINES technique is less space-consuming, relatively simple, cost-effective, and adjustable to the material amounts for treatment. Further the technique does not require pre-treatment of the sludge, such as drying and agglomeration.

Implementing BF sludge recovery by using the technique would improve the steel plants material efficiency and sustainability in regard to returning resources into the supply chain which will save virgin raw materials and reduce environmental impacts by decreasing amount of residual materials going to landfill sites. Furthermore, an industrial implementation contributes to a sustainable energy and material supply by developing the technology to optimally utilise and refine valuable components in residual materials and by cooperation between the steel and base metal industries.

The OXYFINES technique can be used for upgrading both dry and wet fine particulate materials whereof the applications of the technique, and new concept development for the upgrading and recovery of dust and sludge, are conceivable also regarding other applications in steel and ferro alloying industries, or for recycling companies.

\section{Conclusions}

The performed pilot trials aimed to demonstrate the potential of OXYFINES technique for developing a concept of reprocessing BF sludge into useful products. From the results of the pilot trials the following conclusions were drawn:

- The OXYFINES technique is a refining process, not just a transformation, thus it should preferably be used for materials that require both refining and transformation, such as removing zinc from BF sludge.

- The technique is very stable, easily controlled, and flexible for different moisture levels. Furthermore, the technique does not require sludge pre-treatment, such as drying and agglomeration.

- A refined sinter product, with virtually no zinc, and a dry zinc-containing dust, was generated. The sinter, mostly completely melted, was easily crushed into lumps after cooling with almost none fines' generation, making it a suitable product for handling and charging in the steelmaking processes.

- A zinc separation degree of up to $97 \%$ was demonstrated in the performed trials.

- The prerequisites regarding zinc concentration in the generated dust were not met in the trials, whereby further work is required to achieve a desirable zinc content. However, this should be managed through process measures such as decreased leakage air and off-gas filter flow, increased zinc concentration in the BF sludge or by recirculating the generated dust in the OXYFINES process.

- Utilising the BF sludge eliminates the need of new sludge ponds with reduced environmental impact through decreased material deposits.

- Implementation of BF sludge recovery, using OXYFINES technique, would contribute to improved material efficiency and sustainability through the return of resources (mainly iron, carbon, and zinc) from landfills to the value chain with savings in virgin raw materials.

Author Contributions: All authors (F.N., K.B., L.G., D.S., A.W., K.L. and S.R.) were engaged in conceiving and designing the experiments; all authors were also engaged in various ways in performing the experiments; F.N., K.B., S.R. and K.L. analysed the data; F.N., K.B., L.G., D.S. and A.W. contributed equipment $/ \mathrm{materials} / \mathrm{chemical}$ analysis; K.L. wrote the paper. All authors have read and agreed to the published version of the manuscript.

Funding: This research was funded by the Swedish Energy Agency via the strategic innovation programme RE: Source, and the specific call: Innovations for sustainable material use: Development and demonstration. Additional funding was made via the Centre for Process Integration in Metallurgy (PRISMA), at the time of the research work located at Swerim $\mathrm{AB}$. The Centre was supported by its industrial participants, including SSAB Europe, SSAB Merox and Linde Gas AB. 
Acknowledgments: The work presented in this paper was developed within the project “Optimised sludge recycling using OXYFINES technique", Optifines (project number: 46112-1), which has received funding by the Swedish Energy Agency-Energimyndigheten via RE: Source. Additional funding was contributed by the Centre for Process Integration in Metallurgy (PRISMA) and the work was supported by the industrial partners of the project including Linde Gas AB, SSAB Europe, SSAB Merox and Boliden Mineral AB.

Conflicts of Interest: The authors declare no conflict of interest.

\section{References}

1. Branca, T.A.; Colla, V.; Algermissen, D.; Granbom, H.; Martini, U.; Morillon, A.; Pietruck, R.; Rosendahl, S. Reuse and Recycling of By-Products in the Steel Sector: Recent Achievements Paving the Way to Circular Economy and Industrial Symbiosis in Europe. Metals 2020, 10, 345. [CrossRef]

2. Senk, D.; Gudenau, H.W.; Geimer, S.; Gorbunova, E. Dust injection in iron and steel metallurgy. ISIJ Int. 2006, 46, 1745-1751. [CrossRef]

3. Sundqvist Ökvist, L.; Jonsson, K.; Lampinen, H.; Eriksson, L.-E. Recycling of In-Plant Fines as Cold-Bonded Agglomerates. 1-2 June 1999. Available online: https://www.lkab.com/en/SysSiteAssets/documents/kund/ 1999-recycling-of-in-plant-fines-as-cold-bonded--agglomerates.pdf (accessed on 8 September 2020).

4. Sikström, P.; Sundqvist Ökvist, L. Recycling of flue dust into the blast furnace. In Proceedings of the Recycling and Waste Treatment in Mineral and Metal Processing, Luleå, Sweden, 16-20 June 2002.

5. Abdul Azees, S.; Saumit, P.; Rajeev, J. Briquetting: A new approach to recycle the waste iron-bearing materials generated in steel plants. J. Metall. Mater. Sci. 2005, 47, 199-206.

6. Wedholm., A. Briquetting-Taking advantage of fine-grained residues in a sustainable manner. In Proceedings of the SCANMET V 5th International Conference on Process Development in Iron and Steelmaking, Luleå, Sweden, 12-15 June 2016.

7. Besta, P.; Samolejová, A.; Janovská, K.; Lenort, R.; Haverland, J. The Effect of Harmful Elements in Production of Iron in Relation to Input and Output Material Balance. Metalurgija 2012, 51, 325-328.

8. Besta, P.; Janovská, K.; Samolejová, A.; Beránková, A.; Vozňáková, I.; Hendrych, M. The Cycle and Effect of Zinc in the Blast-Furnace Process. Metalurgija 2013, 52, 197-200.

9. Lundkvist, K.; Brämming, M.; Hagemalm, J.; Lagerwall, P.; Wedholm, A. Case Study of Reclaiming Zinc Containing Sludge from Settling Ponds. In Proceedings of the 8th International Congress on Science and Technology of Ironmaking-ICSTI, Vienna, Austria, 25-28 September 2018.

10. Makkonen, H.T.; Heino, J.; Laitila, L.; Hiltunen, A.; Poylio, E.; Harkki, J. Optimisation of steel plant recycling in Finland: Dusts, scales and sludge. Resour. Conserv. Recycl. 2002, 35, 77-84. [CrossRef]

11. Koros, P.J. The 2001 Howe Memorial Lecture, published by permission of the Iron \& Steel Society, "Dusts, Scale, Slags, Sludges Not Wastes, But Sources of Profits". Metall. Mater. Trans. B 2003, 34, 769-778.

12. Guerriero, E.; Bianchini, M.; Gigliucci, P.F.; Guarnieri, A.; Mosca, S.; Rossetti, G.; Varde, M.; Rotatori, M. Influence of Process Changes on PCDD/Fs Produced in an Iron Ore Sintering Plant. Environ. Eng. Sci. 2009, 26, 71-80. [CrossRef]

13. Lu, L.; Ooi, T.C.; Li, X. Chapter 18, Sintering emissions and their mitigation technologies. In Iron OreMineralogy, Processing and Environmental Sustainability; Elsevier, Oxford Woodhead Publishing: Cambridge, UK, 2015; pp. 551-579. ISBN 978-1-78242-156-6.

14. Wang, Z.; Pinson, D.; Chew, S.; Monaghan, B.J.; Rogers, H.; Zhang, G. Mineral Phase Formation and Zinc Removal during Sintering of Filter Cake Wastes. ISIJ Int. 2016, 56, 505-512. [CrossRef]

15. Zhang, H.; Wang, G.; Wang, J.; Xue, Q. Recent Development of Energy-saving Technologies in Ironmaking Industry. In Proceedings of the IOP Conference Series: Earth and Environmental Science, International Conference on Construction, Aviation and Environmental Engineering, Taoyuan City, Taiwan, 23-25 November 2018.

16. Nippon Steel Engineering. Available online: https:/www.eng.nipponsteel.com/english/whatwedo/ steelplants/ironmaking/rotary_hearth_furnace/ (accessed on 25 May 2020).

17. Li, K.; Zhang, J.; Liu, Z.; Mao, R.; Yang, T. Comprehensive Evaluation of OxyCup Process for Steelmaking Dust Treatment Based on Calculation of Mass Balance and Heat Balance. J. Iron Steel Res. Int. 2014, 21, 575-582. [CrossRef]

18. Clay, J.E.; Schoonraad, G.P. Treatment of zinc silicates by the Waelz Process. J. S. Afr. Inst. Min. Metall. 1976, $77,11-14$. 
19. Trinkel, V.; Mallow, O.; Aschenbrenner, P.; Rechberger, H.; Jellner, J. Characterization of Blast Furnace Sludge with Respect to Heavy Metal Distribution. Ind. Eng. Chem. Res. 2016, 55, 5590-5597. [CrossRef]

20. Banerjee, D. Metal recovery from blast furnace sludge and flue dust using leaching technologies. Res. J. Chem. Environ. 2007, 11, 18-21.

21. Li, B.; Wei, Y.; Wang, H.; Yang, Y.; Yin, Y. Preparation of $\mathrm{ZnSO}_{4} \cdot 7 \mathrm{H}_{2} \mathrm{O}$ and Separation of Zinc from Blast Furnace Sludge by Leaching-Purification-Crystallization Method. ISIJ Int. 2019, 59, 201-207. [CrossRef]

22. Trung, Z.H.; Kukurugya, F.; Takacova, Z.; Orac, D.; Miskufova, M.L.A.; Havlik, T. Acidic leaching both of zinc and iron from basic oxygen furnace sludge. J. Hazard. Mater. 2011, 192, 1100-1107. [CrossRef]

23. Vereš, J.; Lovás, M.; Jakabský, Š.; Šepelák, V.; Hredzák, S. Characterization of blast furnace sludge and removal of zinc by microwave assisted extraction, Characterization of blast furnace sludge and removal of zinc by microwave assisted extraction. Hydrometallurgy 2012, 129-130, 67-73.

24. SSAB Luleå. Environmental Report. 2019. Available online: https://www.ssab.se/ssab-koncern/om-ssab/ produktionsorter-i-sverige/lulea (accessed on 8 September 2020).

25. Andersson, A.; Ahmed, H.; Rosenkranz, J.; Samuelsson, C.; Björkman, B. Characterization and upgrading of a low zinc-containing and fine blast furnace sludge-A multi-objective analysis. ISIJ Int. 2017, 57, 262-271. [CrossRef]

26. Butterworth, P.; Linsley, K.; Aumonier, J. Hydrocyclone treatment of blast furnace slurry within British steel. Rev Métall. 1996, 93, 807-815. [CrossRef]

27. Von Schéele, J. OXYFINES ${ }^{\mathrm{TM}}$ Technology for the Re-Melting of fines, Dust and Sludge. In Proceedings of the 10th International Ferroalloys Congress, Cape Town, South Africa, 1-4 February 2004.

28. Jalkanen, H.; Oghbasilasie, H.; Raipala, K. Recycling of Steelmaking Dusts-The Radust Concept. J. Min. Metall. B 2005, 41, 1-16. [CrossRef]

Publisher's Note: MDPI stays neutral with regard to jurisdictional claims in published maps and institutional affiliations. 